\title{
CHANGES IN SERUM PARAOXONASE ACTIVITY, CALCIUM AND LIPID PROFILES IN PRE-ECLAMPSIA, A PRELIMINARY STUDY
}

\author{
Figen BABACAN ${ }^{1}$, Birgul ISIK ${ }^{2}$, Banu BINGOL ${ }^{3}$ \\ ${ }^{1}$ Department of Gynecology and Obstetric, Faculty of Medicine, Dicle University, Diyarbakir, Turkey \\ 2 Department of Biochemistry, Faculty of Medicine, Dicle University, Diyarbakir, Turkey \\ ${ }^{3}$ Department of Gynecology and Obstetric, Gayrettepe Florence Nightingale Hospital, Istanbul Bilim University, \\ Istanbul, Turkey
}

\begin{abstract}
SUMMARY
Objective: To investigate serum paraoxonase (PON1) activity, serum calcium, and lipid profiles in pre-eclampsia. Material and methods: Serum PON1 activity, calcium, and lipid profiles were measured in a cohort of 45 women with normal pregnancies (11 patients) and pre-eclampsia (34 patients).

Results: Triglyceride, total cholesterol, and LDL cholesterol concentrations were significantly increased in women with pre-eclampsia, compared with women with normal pregnancies. Serum HDL cholesterol, PON1, and calcium levels in pre-eclamptic patients were significantly lower than those in healthy pregnant women.
\end{abstract}

Conclusion: The significant decrease of PON1 activity in pre-eclampsia is related to lipid profiles and calcium.

Key words: calcium, lipid profile, Pre-eclampsia, serum paraoxonase (PON1),

Journal of Turkish Society of Obstetrics and Gynecology, (J Turk Soc Obstet Gynecol), 2011; Vol: 8 Issue: 3 Pages: 169- 74

ÖZET

\section{PREEKLAMPSI'DE PARAOKSANAZ AKTIVITESI, KALSIYYUM VE LİPID PROFILLERININ DEĞERLENDİRILMESI, ÖN ÇALIŞMA}

Amaç: Preeklamptik ve normotansif gebelerde serum paraoxonaz (PON1) aktivitesi, serum kalsiyumu ve lipid profillerinin incelenmesi.

Gereç ve yöntemler: 34 preeklamptik ve 11 normotansif gebede serum PON1 aktivitesi, kalsiyum ve lipid profillerinin incelenmesi.

Bulgular: Preeklamptik gebelerde serum trigliserid, total kolesterol, LDL kolesterol sevyeleri, normotansif gebelerle kıyaslandığında anlamlı olarak daha yüksek bulunmuştur. Serum HDL kolesterol, PON1, ve kalsiyum sevyeleri ise normal gebelere klyasla preeklamptik kadınlarda daha düşük olarak tespit edilmiştir.

Sonuç: Preeklamptik hastalarda PON1 aktivitesindeki anlamlı düşüş, lipid profili ve kalsiyum seviyesi ile ilişkilidir.

Anahtar kelimeler: kalsiyum, lipid profili, pre-eklampsi, serum paraoxanaz seviyesi

Türk Jinekoloji ve Obstetrik Derneği Dergisi, (J Turk Soc Obstet Gynecol), 2011; Cilt: 8 Sayl: 3 Sayfa: 169- 74

Yazıșma adresi: Uzm. Dr. Banu Bingöl. cemil Arslan Güder sok. no: 8, 34349 Gayrettepe, İstanbul Türkiye

Tel.: 90 (532) 5667872

e-mail: banubingol1975@yahoo.com

Received: 30 March 2010, revised: 24 January 2011, accepted 09 March 2011, online publication: 09 June 2011 


\section{INTRODUCTION}

Pre-eclampsia is a defined as pregnancy-induced hypertension (systolic blood pressure $>140 \mathrm{~mm} \mathrm{Hg}$ and diastolic blood pressure $>90 \mathrm{~mm} \mathrm{Hg}$ ) with proteinuria (either $\geq 300 \mathrm{mg}$ protein per day or an urinary protein/creatinine ratio $\geq 30 \mathrm{mg} / \mathrm{mmol}$ ) occurring after 20 weeks of gestation. Although this definition uses readily measured clinical parameters, pre-eclampsia must be recognized as a multisystem disorder that may affect the brain, lung, kidney, and liver $(1,2)$.

Pre-eclampsia affects between $0.4 \%$ and $2.8 \%$ of all pregnancies. This common disorder is associated with the highest maternal and fetal morbidity and mortality of all pregnancy complications ${ }^{(3)}$. The cause of preeclampsia remains unknown, but endothelial cell dysfunction is a key feature of its pathogenesis. The cause of the endothelial cell injury is probably multifactorial, but poor placental perfusion plays a major role. In pre-eclampsia, characteristic pathological lesions in the placenta consisting of fibrin deposits, and acute atherosis and thrombosis are present. Abnormalities in lipids are known to be strongly associated with atherosclerotic cardiovascular disease and have direct effects on endothelial function. Abnormal lipid metabolism seems important in the pathogenesis of pre-eclampsia as well(4).

Normal pregnancy is characterized by an elevation of the plasma levels of free fatty acids, triglycerides, cholesterol and low density lipoprotein (LDL) cholesterol $^{(5-7)}$. In pre-eclampsia, even higher levels of triglycerides and lipoproteins may be present $(8,9)$. High levels of triglycerides generally lead to the formation of smaller LDL particles, which are more prone to oxidative modification ${ }^{(6)}$. Oxidatively modified LDL has been shown to play a role in the impairment of vascular endothelial cell function during atherogenesis $(9)$, and may also be involved in the development of pre-eclampsia.

Paraoxonase (aryldialkylphosphatase, E.C 3.1.8.1, PON1) is a serum esterase synthesized in the liver. The enzyme was originally found to be responsible for the hydrolysis of paraoxone, a toxin that irreversibly inhibits acetyl cholinesterase ${ }^{(10-14)}$. PON1 circulates as part of high density lipoprotein (HDL) particles in the blood of humans. The enzyme is tightly bound to the hydrophilic N-terminal domain of Apo-AI. Recently,
PON1 has been shown to inhibit the oxidative modification of $\operatorname{LDL}^{(15)}$, and it is considered to be an antioxidant enzyme with a protective role in atherosclerosis ${ }^{(16)}$. PON1 can destroy active lipids in mildly oxidized LDL, thereby preventing the induction of inflammatory responses in endothelial cells. PON1 is strictly dependent on calcium for enzymatic activity (17-19)

In the present study, we investigated the relationship among serum PON1 activity, serum calcium concentration, and lipid profile in patients with preeclampsia.

\section{MATERIAL AND METHODS}

The study was conducted at the Department of Obstetrics and Gynecology of Dicle University Faculty of Medicine. Thirty-four women with pre-eclampsia and 11 women with normal, normotensive pregnancies were prospectively followed. All of the study related procedures were subjected to local ethics committee approval and the study protocol was approved by Ethical Committee of Dicle University Faculty of Medicine. Pre-eclampsia was diagnosed if blood pressures exceeded 140/90 mm Hg on two separate measurements taken 4 hours apart, after the 20 weeks of gestation, and if proteinuria of more than $300 \mathrm{mg}$ of protein was excreted in 24 hours or if there was greater than $2+$ protein present in a qualitative dipstick test on two samples of urine collected 4 hours apart in the absence of urinary tract infection. HELLP syndrome includes; platelet counts below 50000/microl; lactic dehydrogenase $>$ or $=2000 \mathrm{IU} / \mathrm{I}$; aspartate aminotransferase $>$ or $=500 \mathrm{IU} / \mathrm{I}$; alanine aminotransferase $>$ or $=300 \mathrm{IU} / \mathrm{I}$ and hematuria (20. In our study, we did not have any patients with HELLP syndrome.

All patients had neither pre-existing hypertensive disorders, nor any renal, hepatic or hematological diseases, and they did not receive any medication. None of them were smokers.

Blood samples (approximately $10 \mathrm{ml}$ ) were subjected to centrifugation at $4000 \mathrm{x}$ g for 10 minutes at room temperature. Serum samples were collected and stored at $-20^{\circ} \mathrm{C}$ for one week. PON1 activity was determined as described by Jureticé $\mathrm{D}$ et al ${ }^{(21)}$. Initial rates of hydrolysis of paraoxone (o,o-diethyl-o-p-nitro-phenyl phosphate from Sigma, London, UK) was determined by measuring the absorbance at $405 \mathrm{~nm}$ at $37^{\circ} \mathrm{C}$ with 
a spectrophotometer (Shimadzu UV-1208). This wavelength is the peak of the liberated p-nitrophenyl's absorption spectrum. The assay (reagent) mixture includes $2.0 \mathrm{mmol} / \mathrm{L}$ paraoxone and $2.0 \mathrm{mmol} / \mathrm{L}$ calcium chloride $\left(\mathrm{CaCl}_{2}\right)$ in $0.1 \mathrm{~mol} / \mathrm{L}$ Tris buffer, $\mathrm{pH}$ 8.0. To $350 \mu \mathrm{l}$ of the reagent mixture, $12 \mu \mathrm{l}$ of serum was added. PON1 activity is expressed in units per liter $(\mathrm{U} / \mathrm{L})$ of serum. One unit of activity is defined as $1 \mathrm{mmol}$ p-nitrophenol generated per minute.

Serum levels of AST, ALT, LDH, total cholesterol, HDL-cholesterol, LDL-cholesterol, triglycerides, and calcium were determined using enzymatic assays in an Abbot Aeroset autoanalyzer.

Mann-Whitney $U$ test was used to identify differences between the groups. Data was given as mean \pm S.D.

Differences were considered significant when $\mathrm{P}<0.05$.

\section{RESULTS}

Table I shows the demographic characteristics of the patients. There were no differences in age, parity, and gravidity between the two groups. As expected, women with pre-eclampsia had significantly higher systolic $(\mathrm{P}<0.001)$ and diastolic blood pressures $(\mathrm{P}<0.001)$. Gestational age tended to be lower in women with preeclampsia.

Women with pre-eclampsia had significantly higher levels of hemoglobin, hematocrit, serum AST, ALT, and $\mathrm{LDH}$ than normotensive pregnant women $(\mathrm{P}$ $<0.001$; Table II). Compared to normotensive women, women pre-eclampsia showed lower serum platelet counts $(\mathrm{P}<0.01)$.

Triglycerides, total cholesterol, and LDL-cholesterol

Table I: Demographic and clinical characteristics of the study population.

\begin{tabular}{|c|c|c|c|}
\hline & $\begin{array}{l}\text { Pre-eclamptic } \\
\text { pregnant women }(n=34)\end{array}$ & $\begin{array}{l}\text { Normal pregnant } \\
\text { women }(n=11)\end{array}$ & $P$ value \\
\hline Maternal age (years) & $30.5 \pm 6.1$ & $30.0 \pm 5.8$ & NS \\
\hline Gestational age (weeks) & $34.3 \pm 3.7$ & $37.5 \pm 1.1$ & $<0.002$ \\
\hline Systolic blood pressure (mm Hg) & $155 \pm 18.7$ & $114 \pm 9.3$ & $<0.001$ \\
\hline Diastolic blood pressure (mm Hg) & $97.9 \pm 10$ & $76.3 \pm 6.7$ & $<0.001$ \\
\hline Gravida & $5.0 \pm 3.3$ & $3.6 \pm 2.2$ & NS \\
\hline Parity & $3.8 \pm 3.2$ & $2.5 \pm 2.3$ & NS \\
\hline
\end{tabular}

* Data are given as mean \pm S.D.

Table II: Hematological and biochemical parameters.

\begin{tabular}{|c|c|c|c|}
\hline & $\begin{array}{l}\text { Pre-eclamptic } \\
\text { pregnant women }(n=34)\end{array}$ & $\begin{array}{l}\text { Normal pregnant } \\
\text { women }(n=11)\end{array}$ & $P$ value \\
\hline Hematocrit & $36.13 \pm 3.01$ & $32.81 \pm 2.67$ & $<0.001$ \\
\hline Hemoglobin $(\mathrm{g} / \mathrm{dl})$ & $12.10 \pm 1.26$ & $10.72 \pm 1.34$ & $<0.02$ \\
\hline Platelet count $\left(\mathrm{x} 10^{3} / \mu \mathrm{L}\right)$ & $146 \pm 77.12$ & $219 \pm 62.93$ & $<0.001$ \\
\hline BUN (mg/dl) & $24.43 \pm 7.61$ & $14.45 \pm 2.80$ & $<0.001$ \\
\hline Creatinine (mg/dl) & $9.36 \pm 2.08$ & $4.90 \pm 1.22$ & $=0.16$ \\
\hline $\operatorname{AST}(\mathrm{U} / \mathrm{L})$ & $92.93 \pm 97.38$ & $19.54 \pm 12.20$ & $<0.001$ \\
\hline $\operatorname{ALT}(\mathrm{U} / \mathrm{L})$ & $166.4 \pm 242.8$ & $24.90 \pm 11.97$ & $<0.001$ \\
\hline LDH (U/L) & $783 \pm 660$ & $341 \pm 225$ & $<0.001$ \\
\hline
\end{tabular}

* Data are given as mean \pm S.D.

Table III: Serum levels of cholesterol, triglycerides, calcium, and paraoxonase.

\begin{tabular}{|c|c|c|c|}
\hline & $\begin{array}{l}\text { Pre-eclamptic } \\
\text { pregnant women }(n=34)\end{array}$ & $\begin{array}{l}\text { Normal pregnant } \\
\text { women }(n=11)\end{array}$ & $P$ value \\
\hline Triglycerides (mg/dl) & $281 \pm 101$ & $204 \pm 80$ & $<0.01$ \\
\hline Total cholesterol (mg/dl) & $245 \pm 58$ & $182 \pm 42$ & $<0.0001$ \\
\hline HDL cholesterol (mg/dl) & $46.2 \pm 8.2$ & $62.0 \pm 7.4$ & $<0.0001$ \\
\hline LDL cholesterol (mg/dl) & $162 \pm 39$ & $109 \pm 33$ & $<0.0001$ \\
\hline Calcium (mg/dl) & $7.76 \pm 0.5$ & $9.30 \pm 0.4$ & $<0.0001$ \\
\hline Paraoxonase (U/L) & $108 \pm 63$ & $161 \pm 90$ & $<0.05$ \\
\hline
\end{tabular}

Data are given as mean \pm S.D. 
concentrations were significantly increased in women with pre-eclampsia, compared to normal pregnant women (Table III). Serum HDL-cholesterol, PON1 and calcium levels were lower in pre-eclamptic than in healthy pregnant women $(\mathrm{P}<0.05)$.

In addition, normotensive women had no sings of any complications of pregnancy, and all gave birth to healthy infants.

\section{DISCUSSION}

Pre-eclampsia is one of the most serious complications of pregnancy. The causes of pre-eclampsia are unknown, but evidence suggest that it results from maternal vascular endothelial dysfunction ${ }^{(22)}$. Since oxidized lipids can damage the vascular endothelium, elevated serum triglycerides, total cholesterol, and LDL-cholesterol levels have been suggested to play important roles in the pathogenesis of pre-eclampsia; Branch et al. and Votila et al. found increased serum concentrations of LDL in pre-eclampsia $(23,24)$. Wakatsuki et al. reported that, LDL and HDL particles were more susceptible to oxidative modification and plasma concentration of LDL particles but not of HDL particles was increased in pre-eclampsia ${ }^{(9)}$.

In our study, serum total cholesterol, LDL cholesterol, and HDL cholesterol levels were significantly different between pre-eclamptic and normal pregnant women. Triglycerides, total cholesterol and LDL cholesterol concentrations were significantly increased in women with pre-eclampsia, compared to women with normal pregnancies. This significant elevation in lipid levels in pre-eclampsia is consistent with several previous reports $(25,26)$. In addition, serum calcium levels were significantly lower in pre-eclamptic women. Because PON1 requires calcium ions for both activity and stability, it is tempting to speculate that low calcium might be the cause of decreased PON1 activity. However, there is no available data to support this hypothesis at present. Nevertheless, our findings confirm that low serum PON1 are present in preeclampsia.

Human pregnancy is associated with pronounced physiological hyperlipidemia and the normal gestational increase in triglycerides is associated with a change in LDL profile toward smaller, denser species ${ }^{(27)}$. The elevated serum concentrations of triglycerides and lower concentrations of HDL cholesterol found in preeclampsia patients are in good agreement with the results of other studies $(27,28)$. The elevated concentrations of serum triglycerides in pre-eclampsia can be explained by higher levels of free fatty acid in conjunction with reduced hepatic beta-oxidation, enhanced peripheral insulin resistance, and reduced catabolism of triglycerides ${ }^{(27)}$. Hypertriglyceridemia in pre-eclampsia is proposed to include oxidative stress by promoting changes in the composition of LDL and consequently enhancing the formation of small, dense LDL. In a recent report, a case-control study of 50 women with pre-eclampsia and 101 women with uncomplicated term deliveries was conducted. Maternal serum was collected at 15 to 20 weeks and used to measure paraoxonase 1 activity using two substrates; paraoxon and phenylacetate (arylesterase activity). Paraoxonase 1 activity (oparaoxon) was significantly higher in women with pre-eclipse compared with controls (19.4 \pm 9.4 versus $15.6 \pm 8.0$ chinge in absorbance per minute (dA/min), p: 0.009). When stratified by disease severity, paraoxonase 1 activity (paraoxon) was highest in women with severe pre-eclampsia $(21.6 \pm 9.1$ versus $15.6 \pm 8.0 \mathrm{dA} / \mathrm{min}, \mathrm{p}: 0.002)$. A trend was observed toward higher arylesterase activity in women with preeclampsia compared with controls $(0,343 \pm 0,07$ versus $0,323 \pm 0,06 \mathrm{dA} / \mathrm{min}, \mathrm{p}: 0,06)$. Midgestational paraoxonase 1 activity is higher in women with preeclipse before clinical signs of the disease were present (29).

Human paraoxonase-1 is thought to play a role in preeclampsia and atherosclerosis, mainly through a reduction in LDL oxidation. Oxidized LDL is very important in endothelial dysfunction of pre-eclampsia. Kim et al investigated the association between PON1 gene polymorphism and pre-eclampsia and determined the concentrations of serum lipid in pre-eclamptic patients. They also evaluated serum oxidized LDL levels in normal and pre-eclamptic patients. They reported no significant difference in PON1 genotype frequencies between the control and pre-eclamptic patients. The levels of serum cholesterol and highdensity lipoprotein were significantly lower in preeclamptic patients compared with that of the control group (p: 0,05 and $p<0,01$, respectively). The serum levels of oxidized LDL in pre-eclampsia patients were significantly higher than those in control women ( $\mathrm{p}$ : $0,001)^{(30)}$. 
The results of our study suggest that an abnormal lipid profile and a decrease in the activity of lipophilic antioxidant paraoxonase may play a role in the pathogenesis of preeclampsia through increased susceptibility to lipid peroxidation. Further research is needed to clear the mechanism of this contribution.

\section{REFERENCES}

1. Brown MA, Lindheimer MD, de Swiet M, van Assche A, Moutquin JM. The classification and diagnosis of the hypertensive disorders of pregnancy: statement from the International Society for the Study of Hypertension in Pregnancy (ISSHP) Hypertens Pregnancy; 2001; 20: 9- 14.

2. Curtin WM, Weinstein L. A review of HELLP syndrome. J Perinatol; 1999; 19: 138- 43.

3. Villar K, Say L, Gulmezoglu AM, Merialdi M, Lindheimer MD, Betran AP, Piaggio G. Eclampsia and pre-eclampsia :a health problem for 2000 years. In: Cricthley H, Maclean AB, Poston, Walker JJ, eds. Preeclampsia.London: RCOG Press; 2003: 189- 207.

4. Manten GT, van der Hoek YY, Marko Sikkema J, Voorbij HA, Hameeteman TM, Visser GH, Franx A. The role of lipoprotein (a) in pregnancies complicated by pre-eclampsia. Med Hypotheses; 2005: 64: 162- 9.

5. Sattar N, Gaw A, Packard CJ, Greer IA. Potential pathogenic roles of aberrant lipoprotein and fatty acid metabolism in preeclampsia. Br J Obstet Gynaecol; 1996; 103: 614- 20.

6. Hubel CA, Shakir Y, Gallaher MJ, McLaughling MK, Roberts JM. Low-density lipoprotein particle size decreases during normal pregnancy in association with triglyceride increase. J Soc Gynecol Invest; 1998: 5: 244- 50.

7. Rosing U, Samsioe G, Olund A, Johansson B, Kallner A. Serum levels of apolipoprotein A-1, A-II and HDL cholesterol in second half of normal pregnancy and in pregnancy complicated by preeclampsia. Horm Metab Res; 1989; 21 : 376- 82 .

8. Hubel CA, McLaughlin MK, Evans RW, Hauth BA, Sims CJ, Roberts JM. Fasting serum triglycerides, free fatty acids, and malondialdehyde are increased in preeclampsia, are positively correlated, and decrease within 48 hours post partum. Am J Obstet Gynecol; 1996; 174: 975- 82.

9. Wakatsuki A, Ikenoue N, Okatani Y, Shinohara K, Fukaya T. Lipoprotein particles in preeclampsia: susceptibility to oxidative modification. Obstet Gynecol; 2000; 96: 55- 9.

10. La Du B. Human serum paraoxonase/arylesterase. Pharmacogenetics of Drug Metabolism. W. Kalow, editor. Pergamon Press, New
York.; 1992: 51: 191.

11. La Du BN, Adkins S, Chung-Liang AK, Lipsig D. Studies on human serum paraoxonase/arylesterase. Chem Biol Interact; 1993; 87: 25- 34 .

12. Mackness B, Durrington PN, Mackness MI. Human serum paraoxonase. Gen Pharmacol; 1998; 31: 329- 36

13. Mackness B, Durrington P N, Fogelman AM, Berliner J, Lusis AJ, Navab M, Shih D, Fonarow GC. Paraoxonase and coronary heart disease. Curr Opin Lipidol; 1998; 9: 319- 24.

14. Hegele R. Paraoxonase genes and disease. Ann Med; 1999; 31: $217-24$

15. Mackness MI, Durrington PN. HDL, its enzymes and its potential to influence lipid peroxidation. Atherosclerosis; 1995; 115: 243- 53.

16. Azarsiz E, Sozmen EY. Paraoxonase and clinical importance. Turkish Journal of Biochemistry; 2000; 25: 109- 19.

17. Mackness M. Human serum paraoxonase is inhibited in EDTA plasma. Biochem Biophys Res Commun; 1998; 242: 249.

18. Aviram M, Billecke S, Sorenson R, Bisgaier C, Newton R, Rosenblat M, Erogul J, Hsu C, Dunlop C, La Du B. Paraoxonase active site required for protection against LDL oxidation involves its free sulfhydryl group and is different from that required for its arylesterase/paraoxonase activities: selective action of human paraoxonase allozymes Q and R. Arterioscler Thromb Vasc Biol; 1998; 18: 1617- 24.

19. Cao H, Girard-Globa A, Berthezene F, Moulin P. Paraoxonase protection of LDL against peroxidation is independent of its esterase activity towards paraoxon and is unaffected by the QR genetic polymorphism. J Lipid Res; 1999; 40: 133- 9.

20. Vigil De Gracia P. Pregnancy complicated by pre-eclampsiaeclampsia with HELLP syndrome. Int J Gynaecol Obstet. 2001; 72(1): 17- 23.

21. Juretic D,Tadijanovic M, Rekic B, Simeon-Rudolf V, Reiner E, Baricic M. Serum paraoxonase activities in hemodialyzed uremic patients: cohort study. Croat Med J; 2001; 42: 146- 50.

22. Harma MI, Harma M, Erel O. Measurement of the total antioxidant response in preeclampsia with a novel automated method. Eur J Obstet Gynecol Reprod Biol; 2005; 118: 4751.

23. Branch DW, Mitchell MD, Miller E, Palinski W, Witztum JL. Preeclampsia and serum antibodies to oxidised low-density lipoprotein. Lancet; 1994; 343: 645- 6.

24. Uotila J, Solakivi T, Jaakkola O, Tuimala R, Lehtimaki T. Antibodies against copper oxidised and malondialdehydemodified low density lipoproteins in pre-eclampsia pregnancies. Br J Obstet Gynaecol; 1998; 105: 1113- 7.

25. Kumru S, Aydin S, Gursu MF, Ozcan Z. Changes of serum paraoxonase (HDL cholesterol associated lipophilic antioxidant) 
and arylesterase activities in severe preeclamptic women. Eur J Obstet Gynecol Reprod Biol; 2004; 114: 177- 81.

26. Belo L, Caslake M, Gaffney D, Santos-Silva A, Pereira-Leite L, Quntanilha H, Rebelo I. Changes in LDL size and HDL concentration in normal and preeclamptic pregnancies. Atherosclerosis; 2002; 162: 425- 32.

27. Sattar N, Bendomir A, Berry C, Shepherd J, Greer IA, Packard CJ. Lipoprotein subfraction concentrations in preeclampsia: pathogenic parallels to atherosclerosis. Obstet Gynecol. 1997; 89(3): 403-8.

28. Ware-Jauregui S, Sanchez SE, Zhang C, Laraburre G, King
IB, Williams MA. Plasma lipid concentrations in pre-eclamptic and normotensive Peruvian women. Int J Gynaecol Obstet. 1999; 67(3): 147- 55.

29. Baker AM, Klein RL, Haeri S, Moss KL, Boggess KA. Association of midgestational paraoxonase 1 activity with pregnancies complicated by preeclampsia. Am J Perinatol. 2010; 27(3): 205- 10.

30. Kim YJ, Park H, Lee HY, Ahn YM, Ha EH, Suh SH, Pang MG. Paraoxonase gene polymorphism, serum lipid, and oxidized low-density lipoprotein in preeclampsia. Eur J Obstet Gynecol Reprod Biol. 2007; 133(1): 47- 52. 